\title{
PENATALAKSANAAN CAIRAN PERIOPERATIF PADA KASUS TRAUMA
}

\author{
Iddo Posangi \\ Bagian Anestesiologi Fakultas Kedokteran Universitas Sam Ratulangi Manado \\ Email: iddoposangi@gmail.com
}

\begin{abstract}
Trauma can be defined as a physical harm or damage to the structure or function of the body, caused by an acute exchange of mechanical, chemical, thermal, radioactive, or biological energy that exceeds the body's tolerance. The commonly used resuscitation fluids are Ringer's Lactate solution, normal saline, colloids, hypertonic saline, and blood products (packed red blood cells, fresh frozen plasma, or platelets). Fluid resuscitation strategy consists of early resuscitation and late resuscitation. The management of perioperative fluid therapy in traumatized cases requires a comprehensive understanding regarding the pathophysiology of shock, the consequences of fluid therapy in ongoing bleeding, and the ability to apply the evidence-based studies on each individual with different clinical status.
\end{abstract}

Key words: trauma, fluid resuscitation, shock

\begin{abstract}
Abstrak: Trauma dapat didefinisikansebagai cedera atau kerusakan fisik dari struktur atau fungsi tubuh yang disebabkan oleh perubahan energi akut(mekanis, kimiawi, radioaktif, biologik) yang melampaui toleransi tubuh. Cairan resusitasi yang umunya digunakan pada kasus trauma ialah larutan Ringer laktat, $\mathrm{NaCl}$ fisiologis, koloid, $\mathrm{NaCl}$ hipertonik dan produk darah (packed red blood cells, plasma beku atau trombosit). Strategi resusitasi cairan terdiri dari resusitasi fase awal dan fase akhir. Penatalaksanaan terapi cairan perioperatif pada kasus trauma memerlukam pemahaman yang menyeluruh mengenai patofisiologi syok, efek terapi cairan pada saat perdarahan aktif, dan kemampuan untuk menerapkan bukti ilmiah pada masing-masing individu dengan keadaan klinis yang berbeda.
\end{abstract}

Kata kunci: trauma, resusitasi cairan, syok

Trauma adalah cedera atau kerusakan fisik dari struktur atau fungsi tubuh yang disebabkan oleh perubahan energi (mekanis, kimiawi, radioaktif, dan biologik) yang mendadak yang melampaui toleransi tubuh. ${ }^{1}$ Trauma merupakan masalah kesehatan masyarakat di seluruh dunia dan merupakan penyebab morbiditas dan mortalitas pada usia muda, terlebih khusus pada negara industri. Menurut WHO terdapat 5,8 juta kasus fatal akibat trauma pada tahun 2000 sehingga trauma tergolong sebagai penyebab kematian terbanyak ke-7 di dunia. Di Amerika Serikat trauma merupakan penyebab kematian terbanyak. ${ }^{2}$ Trauma yang menyebabkan kematian dan kecacatan ini meningkat seiring dengan meningkatnya jumlah produk industrialisasi mobil. Untuk itu WHO mencetuskan kampanye global tentang pencegahan dan kesadaran guna menurunkan angka trauma akibat kecelakaan. Pada anak, kecelakaan lalu lintas merupakan penyebab utama trauma dan kematian sedangkan kasus tenggelam sebesar $10-27 \%$ yang kemudian menjadi $4 \%$ pada usia di atas 15 tahun. Pada pasien berusia di atas 80 tahun, jatuh merupakan penyebab utama terjadinya kematian pada kasus trauma. $^{2}$

Trauma dikategorikan berdasarkan tiga gambaran utama: 1) mekanisme cedera, 2) kekuatan biomedik yang menyebabkan 
cedera, 3) cedera yang disengaja atau tidak. Mekanisme trauma meliputi antara lain trauma mekanik, listrik, radiasi, dan ledakan. Untuk setiap mekanisme tersebut terdapat agen yang menyebabkan cedera. Cedera mekanik dapat terjadi karena trauma tumpul atau trauma tembus. Contoh trauma tumpul antara lain kecelakaan lalu lintas, baik tabrakan antar mobil maupun tabrakan mobil dengam pejalan kaki. Trauma tembus dapat disebabkan oleh pisau, luka tembak, benda tajam maupun serpihan ledakan bom. Trauma panas dapat disebabkan oleh api, uap maupun zat kimiawi. Trauma listrik dapat disebabkan oleh arus langsung maupun sambaran petir. Trauma ledakan dapat berhubungan dengan ledakan Industri, bom, maupun kegiatan teroris. Trauma radiasi dapat disebabkan kesalahan pada penelitian, nuklir, maupun kegiatan teroris. ${ }^{2}$

\section{PILIHAN CAIRAN RESUSITASI}

Cairan kristaloid isotonik merupakan cairan awal yang digunakan pada kebanyakan pasien trauma. Keuntungan cairan ini yaitu murah, siap tersedia, tidak alergik, tidak infeksius, dan efektif untuk mengembalikan cairan tubuh. Cairan kristaloid relatif mudah penyimpanannya, mudah bercampur dengan obat-obatan intravena dan dapat cepat dihangatkan. Kekurangan cairan kristaloid yaitu rendahnya kemampuan mengantarkan oksigen, rendahnya kemampuan koagulasi, dan keterbatasan half-life di intravaskuler. ${ }^{3}$

\section{Ringer Laktat}

Sydney Ringer (1882) menghasilkan cairan garam fisiologik seimbang yang ditelitinya pada jantung katak. Seorang dokter spesialis anak, Alexis Hartmann (1930-an) mendapat kesulitan mengobati penderita kolera yang asidosis karena pada saat melakukan sterilisasi larutan garam dengan bikarbonat yang diramunya mengalami kehilangan $\mathrm{CO}_{2}$. Kemudian Hartmann mencampur Na-laktat $\left(\mathrm{Na}-\mathrm{C}_{3} \mathrm{H}_{5} \mathrm{O}_{3}\right)$ ke dalam larutan Ringer, maka "lahirlah" cairan Ringer laktat (di Inggris masih disebut sebagai cairan Hartmann). Ringer Laktat (RL) merupakan cairan resusitasi utama yang digunakan di pusat trauma di Amerika dan Kanada.Komposisi RL dibuat menyerupai plasma, dan laktat ditambahkan sebagai buffer. Metabolisme intrahepatik akan mengubah laktat menjadi bikarbonat melalui proses glukoneogenesis dengan terjadi peningkatan glukosa plasma sebanyak 50-100 mg/dL pada setiap liter. Pada resusitasi cairan yang dikarenakan perdarahan, kebanyakan pasien trauma akan mengalami asidosis laktat. RL merupakan pilihan pertama untuk resusitasi sedangkan normal saline (NS) merupakan pilihan kedua. Walaupun NS merupakan pengganti volumee yang memuaskan pada pasien trauma namun NS berpotensi menyebabkan asidosis hiperkloremik. ${ }^{3}$

Penelitian tentang perdarahan dan resusitasi pada tikus oleh Healey et al, menunjukkan bahwa NS dan RL mempunyai efek yang sama pada perdarahan $36 \%$ estimated blood volumee (EBV), namun pada keadaan perdarahan dua kali EBV terjadi peningkatan angka asidosis secara bermakna dengan angka mortalitas meningkat $50 \%$ pada kelompok NS dibandingkan kelompok RL. Hasil ini hampir sama dengan penelitian Coran et al, yang membandingkan RL dan NS pada anjing. Sejak saat itu diketahui bahwa penggunaan NS dengan jumlah yang banyak dapat menyebabkan asidosis hiperkloremik. RL mengandung $28 \mathrm{mmol} / \mathrm{L}$ laktat dalam campuran L-laktat dan D-laktat 50:50. L-laktat dimetabolisme di hepar dan ginjal menjadi piruvat kemudian menjadi $\mathrm{HCO}_{3}^{-}+\mathrm{CO}_{2}+$ $\mathrm{H}_{2} \mathrm{O}$, atau $\mathrm{HCO}_{3}{ }^{-}+$glukosa, untuk cadangan buffer. D-laktat tidak dapat dimetabolisme sehingga diperkirakan menjadi penyebab terjadinya asidosis. Beberapa penulis menyarankan untuk menghindari penggunaan RL pada kasus dengan peningkatan laktat. Telah dibuktikan bahwa penggunaan cairan RL untuk resusitasi berpotensi menyebabkan terjadinya aktivasi leukosit polimorfonuklear sehingga dapat mencederai paru-paru.Walaupun resusitasi menggunakan RL memperbaiki parameter hemodinamik setelah syok hemoragik, namun RL 
dapat memengaruhi sistem imun dengan cara mengubah fungsi leukosit. Harus diingat bahwa RL bukan cairan isotonik namun sedikit hipotonik (273 mOsmol/l), sehingga ahli bedah saraf lebih menyukai NS daripada RL. ${ }^{4}$

\section{$\mathrm{NaCl}$ fisiologis}

$\mathrm{NaCl}$ fisiologis merupakan cairan kristaloid sedikit hipertonik dengan komposisi natrium dan klorida yang lebih tinggi dari plasma. Cairan ini tidak mengandung kalsium sehingga digunakan untuk dilusi produk transfusi darah, supaya tidak timbul kemungkinan terjadinya gangguan dengan antikoagulan sitrat. Resusitasi menggunakan cairan ini dalam jumlah yang banyak akan menimbulkan asidosis metabolik hiperkloremik. Cairan ini lebih jarang digunakan pada resusitasi syok perdarahan. Penelitian terhadap hewan menunjukkan bahwa angka mortalitas lebih tinggi pada penggunaan NS jika dibandingkan dengan $\mathrm{RL}^{3}$

\section{Koloid}

Cairan koloid sejak lama telah dikenal untuk mengisi volume plasma dengan cepat. Seperti halnya kristaloid, koloid siap tersedia, mudah disimpan dan digunakan. Koloid bekerja meningkatkan volume intravaskuler dengan cara menarik cairan bebas kembali ke intravaskuler. Jika akses intravena terbatas, resusitasi koloid akan mengembalikan volume intravaskuler lebih cepat daripada kristaloid. Sama seperti kristaloid, koloid tidak memfasilitasi transpor oksigen maupun pembekuan darah, sehingga efek dilusinya serupa dengan kristaloid. Jenis koloid yang sering digunakan yaitu albumin, gelatin, starch, dekstran, dan plasma. $^{4}$

\section{Kristaloid versus koloid}

Sampai saat ini belum terdapat bukti yang menunjukkan cairan mana lebih baik untuk penggantian volume cairan intravaskuler. Cairan koloid akan bertahan lebih lama di intravaskuler sehingga jumlah yang diperlukan untuk mengisi volume intra- vaskuler lebih sedikit. Para pemberi kristaloid pada umumnya menganjurkan hukum 3:1 karena hanya sepertiga cairan kristaloid yang bertahan di dalam intravaskuler. ${ }^{5}$ Suatu meta-analisis membandingkan kristaloid dan koloid pada tahun 1989 menyimpulkan bahwa pasien trauma sebaiknya diresusitasi dengan menggunakan cairan kristaloid sedangkan pasien pembedahan elektif nontrauma dan nonseptik diresusitasi dengan koloid. Meta-analisis lanjutan oleh Choi et al, menunjukkan bahwa tidak terdapat perbedaan bermakna dalam halterjadinya edema paru, mortalitas, lama inap pasien antara resusitasi menggunakan cairan kristaloid dengan koloid pada populasi umum, namunangka mortalitas lebih rendah pada pasien dengan pemberian kristaloid. Secara Cochrane Review dalam Randomized Controlled Trials (RCT) tidak membuktikan bahwa resusitasi menggunakan koloid menurunkan risiko kematian dibandingkan dengan resusitasi menggunakan kristaloid pada pasien trauma atau luka bakar. Kesimpulan sementara yaitu bahwa pro dan kontra terhadap cairan kristaloid dan koloid sampai saat ini masih terus berlangsung dan penelitian tentang kristaloid dan koloid masih harus dilanjutkan.,

\section{Hypertonic saline}

Cairan hypertonic saline (HS), tanpa atau dengan tambahan polimer dextran (HS atau HSD) telah banyak diteliti pada resusitasi syok perdarahan. Campuran 6\% dekstran 70 dengan HS 7,5\% telah disetujui di beberapa negara Eropa sebagai cairan resusitasi untuk jumlah kecil (4 ml/ $\mathrm{kg}$, biasanya $20 \mathrm{ml} / \mathrm{kg}$ ). Berbagai studi yang dilakukan pada hewan dengan perdarahan letal menunjukkan peningkatan angka harapan hidup jika menggunakan HSD dibandingkan dengan HS. Studi tentang penggunaan HSD pada pasien trauma umumnya bersifat suportif. Keuntungan dari penggunaan HS pada pasien trauma multipel dengan traumatic brain injury (TBI) menunjukkan perbaikan status neurologik. HS dan HSD terbukti dapat menurunkan 
aktivitas netrofil sesudah resusitasi. Menurut Coimbra et al, resusitasi menggunakan HS dapat menurunkan kemungkinan terjadinya sepsis pada syok hemoragik. ${ }^{6}$

\section{Produk darah}

Ketersediaan produk darah merupakan hal yang penting. Berkurangnya kemampuan mengangkut oksigen akan mempersulit manajemen syok hemoragik sehingga menyebabkan iskemia jaringan walaupun dengan cardiac output yang tinggi. Perlu diingat bahwa hemodilusi harus dihindari pada awal terjadinya syok hemoragik, baik untuk cadangan hematokrit maupun untuk hemostasis.

\section{Packed red blood cells (PRBC)}

PRBC golongan darah $\mathrm{O} \mathrm{Rh}(-)$ tanpa crossmatch harus selalu tersedia di pusat trauma manapun sebab dapat langsung diberikan. PRBC jenis ini harus segera diberikan pada pasien dengan syok akibat perdarahan yang sedang berlangsung. Selanjutnya darah yang telah menjalani proses crossmatch harus segera diberikan. Satu kantong PRBC rata-rata akan meningkatkan hematokrit sebanyak 3\% atau hemoglobin sebesar $1 \mathrm{~g} / \mathrm{dL}$ pada pasien dengan berat badan $70 \mathrm{~kg}$ tanpaperdarahan.Risiko pemberian PRBC yaitu reaksi transfusi, transmisi infeksi dan hipotermi. PRBC disimpan pada suhu $4^{0} \mathrm{C}$ sehingga akan menurunkan suhu pasien dengan cepat jika tidak dimasukkan melalui penghangat atau dicampur dengan kristaloid isotonik. Mencampur darah dengan kristaloid juga akan mengurangi viskositas PRBC sehingga bisa lebih mudah masuk intravena. Transfusi cepat PRBC berisiko terjadi intoksikasi sitrat pada resepien. PRBC dikemas dengan sitrat untuk berikatan dengan kalsium bebas sehingga menghambat kaskade pembekuan darah. Transfusi PRBC dalam jumlah banyak dengan cepat menyebabkan tubuh tidak mampu untuk menyediakan kalsium bebas, sehingga terjadi penurunan kalsium bebas dalam darah. Hipokalsemia yang tidak diketahui penyebabnya merupakan penyebab lazim terjadinya hipotensi menetap walaupun telah dilakukan resusitasi cairan dengan volume yang adekuat. Kadar ion kalsium sebaiknya diperiksa dan kalsium intravena sebaiknya diberikan jika diperlukan. American Society of Anesthesiologists (ASA) merekomendasikan transfusi PRBC pada kadar hemoglobin kurang dari $6 \mathrm{~g} / \mathrm{dL}$ dan tidak merekomendasikan transfusi di atas $10 \mathrm{~g} / \mathrm{dL}$. Pemberian transfusi pada kadar hemoglobin 6$10 \mathrm{~g} / \mathrm{dL}$ didasarkan pada pendekatan individual, dengan mempertimbangkan adanya iskemi organ, kecepatan dan jumlah perdarahan, status volume intravaskuler, dan risiko jika terjadi oksigenasi yang tidak adekuat. Sebagai contoh: pada pasien dengan cadangan kardiopulmoner yang rendah dan konsumsi oksigen tinggi. ${ }^{6}$

\section{Plasma}

Terapi plasma diindikasikan pada pasien yang telah menjalani transfusi PRBC pada fase akut sebanyak enam kantong. ${ }^{6}$ Plasma seharusnya diberikan lebih awal pada pasien dengan traumabermakna dan adanya perdarahan aktif. Cryoprecipitate atau preparat faktor koagulasi lainnya jarang diperlukan kecuali ditemukan adanya defisiensi kongenital. Bukti terakhir dari perang di Iraq menyebutkan bahwa whole blood lebih superior daripada terapi komponen darah. Jika whole blood tidak tersedia, fresh frozen plasma (FFP): PRBC dengan rasio 1:1 atau 1:2 terbukti dapat meningkatkan volumee intravaskuler dan memperbaiki faktor koagulasi yang hilang akibat transfusi kristaloid yang masif. ${ }^{6}$

\section{Platelet}

Jumlah platelet tetap adekuat selama proses perdarahan pasien trauma jika dibandingkan dengan hematokrit atau parameter koagulasi lainnya, namun transfusi platelet diindikasikan jika terjadi perdarahan akut lebih dari 1,5 kali volumee darah pasien. Transfusi platelet diberikan pada pasien dengan perdarahan masif dan pada pasien yang secara klinis mengalami koagulopati dengan kadar platelet yang rendah (50.000). Platelet tidak boleh diberi- 
kan melalui filter karena dapat mengurangi kuantitas yang sampai ke jaringan. ${ }^{6}$

\section{STRATEGI RESUSITASI CAIRAN}

Terapi cairan merupakan kunci dari resusitasi. Pada pasien trauma umumnya terjadi perubahan berupa berkurangnya aliran darah sirkulasi akibat perdarahan internal maupun eksternal. Pemahaman bahwa saat terjadi perdarahan butuh penggantian cairan sudah jelas: tubuh kehilangan cairan sehingga cairan tersebut harus diganti. $^{6,7}$ Dikenal duafase resusitasi: (1) resusitasi fase awal, saat perdarahan masih berlangsung; (2) resusitasi fase akhir, saat perdarahan telah dikontrol. Pemberian cairan intra vena diperkirakan akan meningkatkan curah jantung dan tekanan darah pada pasien hipovolemik yang mengalami trauma. Kurikulum ATLS (Advanced Trauma Life Support) menyarankan pemberian cairan infus isotonik kristaloid sampai 2 liter pada pasien hipotensi dengan tujuan menormalkan tekanan darah. Keefektifan teknik ini dipertanyakan, mengingat bahwa pemberian cairan agresif dianalogikan dengan menumpahkan air ke dalam ember yang bocor, di mana semakin besar tekanan yang ada pada ember, semakin banyak air yang hilang. Selain hal itu, penggunaan cairan yang tidak mengandung eritrosit, trombosit, maupun faktor koagulasi akan menyebabkan hemodilusi, bahkan lebih dari keadaan hemodilusi yang disebabkan oleh perdarahan itu sendiri. Resusitasi yang kurang mengakibatkan perdarahan yang lebih sedikit, namun lebih berisiko terjadi iskemia akibat vasokonstriksi dan hipoperfusi yang lama. $^{7}$

Risiko yang dapat terjadi sehubungan dengan penggantian cairan volumee yang agresif pada resusitasi awal: peningkatan tekanan darah, penurunan viskositas darah, penurunan hematokrit, penurunan konsentrasi faktor-faktor pembekuan, kebutuhan transfusi lebih besar, gangguan keseimbangan elektrolit, supresi imun langsung, reperfusipremature, dan peningkatan risiko hipotermia. $^{7}$

Teknik hipotensi pada pembedahan merupakan teknik yang sudah lazim digunakan pada operasi elektif seperti operasi penggantian sendi, fusi spinal, diseksi leher radikal, pembedahan rekonstruksi wajah dan sebagainya. Penggunaan teknik ini pada penanganan kasus dengan perdarahan masih merupakan perdebatan. Perbedaan klinis antara pasien yang menjalani pembedahan elektif dan pembedahan pasien darurat akibat trauma dengan teknik hipotensi dapat dilihat pada Tabel 2.

Tahun 1965, Shaftan et al, membandingkan jumlah darah yang hilang akibat trauma arteri pada anjing. Hasilnya menunjukkan bahwa jumlah darah yang hilang lebih sedikit pada hewan yang dibuat hipotensi dibandingkan dengan hewan yang mendapat infus agresif. ${ }^{7}$ Pembatasan cairan intravaskuler dan tekanan darah pada hewan yang mengalami perdarahan lebih menguntungkan. Burriset al menggunakan teknik resusitasi dengan cairan kombinasi HS dan dekstran menyimpulkan bahwa angka ketahanan hidup paling baik pada

Tabel 2. Perbedaan klinis antara pembedahan pasien elektif dan pembedahan pasien darurat akibat trauma dengan teknik hipotensi. ${ }^{7}$

\begin{tabular}{ccc}
\hline Aspek & Elektif & Trauma \\
\hline Volumee intravaskuler & Euvolemik & Hipovolemik \\
Suhu & Normal & Cenderung hipotermi \\
Kapiler & Dilatasi & Konstriksi \\
Stadium anestesi & Dalam & Biasanya dangkal \\
Status mental & Normal & Mungkin terganggu \\
Trauma penyerta & Tidak ada & Mungkin bermakna \\
Penyakit medik lain & Diketahui dan ditangani & Tidak diketahui \\
\hline
\end{tabular}


kelompok yang diresusitasi dengan tekanan darah arterial rerata yang lebih rendah dari normal.

Konsensus panel tahun 1994 menyatakan bahwa hewan mamalia mampu bertahan hidup pada tekanan darah arterial rerata serendah $40 \mathrm{mmHg}$ selama 2 jam tanpa mengalami efek yang dapat mengancam nyawa. Simpulan dari konsensus tersebut yaitu angka hemostasis spontan dan ketahanan hidup lebih tinggi terjadi pada kelompok yang pemberian cairan resustasinya lebih sedikit saat perdarahan aktif; targetnya yaitu mencapai perfusi sedikit di atas ambang batas terjadinya iskemia. ${ }^{8}$

Penelitian prospektif pertama menggunakan teknik resusitasi hipotensi pada trauma torso ditunjukkan di bawah ini. Pasien dibagi dalam dua kelompok, kelompok pertama yaitu pasien yang mendapatkan resusitasi standar (infus 2 L kristaloid) dan kelompok kedua yaitu pasien yang resusitasinya ditunda (tidak diberikan cairan infus sampai pasien masuk kamar operasi). Studi yang berlangsung selama 37 bulan ini mencakup 598 pasien. Waktu transpor dan penanganan rata-rata dari tempat kejadian sampai ke unit gawat darurat yaitu 30 menit, dan 50 menit sampai ke kamar operasi. Kelompok yang resusitasinya ditunda ratarata mendapatkan cairan infus sejumlah $800 \mathrm{ml}$ sedangkan kelompok yang mendapatkan resusitasi standar rata-rata mendapatkan cairan infus kristaloid sejumlah $2500 \mathrm{ml}$ dan transfusi darah sejumlah 130 cc. Tekanan darah saat tiba di kamar operasi pada kedua kelompok ini tidak berbeda, sehingga peneliti menjadikan bukti bahwa kelompok yang resusitasinya ditunda mengalami hemostasis spontan. Angka ketahanan hidup dan angka kepulangan dari rumah sakit pada kelompok pasien yang ditunda resusitasinya secara bermakna lebih baik dari kelompok resusitasi standar $(70 \%$ versus $62 \%$ dengan $\mathrm{P}=0,04)^{8}$

Pada tahun 2002 dilakukan studi prospektif kedua mengenai resusitasi pada pasien trauma. ${ }^{9}$ Pasien perdarahan dengan tekanan darah sistolik kurang dari $90 \mathrm{~mm}$ Hg dibagi dalam dua kelompok, kelompok pertama dilakukan resusitasi hingga tekanan darah sistolik mencapai $100 \mathrm{~mm}$ $\mathrm{Hg}$ (grup normal) dan kelompok kedua dilakukan resusitasi hingga tekanan darah sistolik mencapai $70 \mathrm{~mm} \mathrm{Hg}$ (grup studi). Hasil dari penelitian ini dapat dilihat pada Tabel 3.

Temuan pada penelitian ini serupa dengan temuan penelitian sebelumnya yang menyimpulkan bahwa hipotensi menyebabkan terjadinya auto resusitasi dan berhentinya perdarahan. Tekanan darah akan kembali naik tanpa pemberian cairan infus jika hemostasis telah tercapai. Dalam 24 jam pertama, laktat dan base deficit pada kedua kelompok kembali normal, dan dibutuhkan jumlah cairan infus dan produk darah yang relatif sama, sehingga disimpulkan bahwa target akhir resusitasi yang dicapai kedua kelompok ialah ekuivalen. Pada penelitian ini disimpulkan bahwa

Tabel 3. Hasil Penelitian Dutton et al (2002). Perbandingan Perbedaan Perlakuan Resusitasi Pada Pasien Trauma dengan Pencapaian Tekanan Sistolik100 mm Hg dan $70 \mathrm{~mm} \mathrm{Hg} .{ }^{9}$

\begin{tabular}{lccc}
\hline & Konvensional & Hipotensi & Total \\
\hline Jumlah Pasien & 55 & 55 & 110 \\
Lelaki & 46 & 41 & 87 \\
Trauma tumpul & 22 & 31 & 53 \\
Trauma tembus & 33 & 24 & 57 \\
Skor trauma & 19,65 & $23,62(P=0.11)$ & \\
Prediksi bertahan & 0,94 & $0,90(P=0.19)$ & \\
Tekanan darah sistolik saat studi & & & \\
Bertahan hidup sampai pulang & 114 & $100(P<0.001)$ & \\
& 4 & 4 &
\end{tabular}


pemberian cairan infus pada pasien dengan perdarahan aktif harus dititrasi untuk mencapai target fisiologik yang spesifik, di satu sisi mempertimbangkan risiko terjadinya peningkatan perdarahan, namun di sisi lain menghindari terjadinya hipoperfusi. Target untuk resusitasi di fase awal: ${ }^{7}$ pertahankan tekanan darah sistolik antara 80-100 mm $\mathrm{Hg}$, pertahankan hematokrit antara $25 \%$ $30 \%$, pertahankan trombosit lebih dari $50.000 / \mathrm{mm}^{3}$, pertahankan suhu tubuh sentral di atas $35^{\circ} \mathrm{C}$, pertahankan fungsi pulse oximeter, mencegah kenaikan serum laktat, mencegah terjadinya asidosis yang lebih memburuk, memberikan anestesi dan analgesi. $^{7}$

Penelitian klinis mengenai teknik resusitasi hipotensi dihindari pada populasi yang diperkirakan lebih berisiko untuk timbul komplikasi akibat iskemia, yaitu pasien dengan penyakit jantung koroner, usia lanjut, dan pasien dengan trauma otak dan medula spinalis. Pasien usia lanjut yang mengalami trauma hasil akhirnya lebih buruk jika dibandingkan pasien usia muda, hal ini dikarenakan cadangan fisiologis mereka yang sudah berkurang. Jadi, teknik hipotensi resusitasi kasus trauma pada pasien trauma otak dan pasien usia lanjut sebaiknya dihindari. ${ }^{7,9}$

Resusitasi di fase akhir dimulai ketika perdarahan sudah bisa dikontrol melalui pembedahan, angiografi, maupun hemostasis spontan. Capaian target pada fase ini yaitu mengembalikan perfusi normal semua sistem organ sambil tetap mempertahankan fungsi vital. Target untuk resusitasi di fase akhir yaitu mempertahankan tekanan darah sistolik di atas $100 \mathrm{~mm} \mathrm{Hg}$, hematokrit di atas ambang batas transfusi individual, status koagulasi yang normal, keseimbangan elektrolit, suhu tubuh yang normal dan produksi urin yang normal, serta memaksimalkan curah jantung dengan pengukuran invasif maupun non-invasif, memperbaiki asidosis sistemikdan mempertahankan serum laktat normal. ${ }^{9}$

\section{SIMPULAN}

Penatalaksaan cairan perioperatif pada pasien trauma memerlukan pemahaman yang menyeluruh mengenai patofisiologi syok, efek terapi cairan pada saat perdarahan aktif, dan kemampuan untuk menerapkan bukti ilmiah pada masing-masing individu dengan keadaan klinis yang berbeda. Tatalaksana cairan merupakan seni mengenai kapan harus menyesuaikan terapi cairan, membatasi cairan, memberikan cairan secara agresif dan menggunakan inotropik, serta bagaimana menilai trauma pasien dan responnya terhadap terapi. Jenis, jumlah dan waktu pemberian cairan bervariasi sesuai keadaan klinis pasien.

\section{DAFTAR PUSTAKA}

1. Barbieri P, Gomez DH, Mahoney PF, Pratesi P, Grande CM. Mechanisms and demographics in trauma. In: Smith CE, editor. Trauma anesthesia. Cambridge: Cambridge University Press, 2008; p.1-8.

2. Potenza B, Nolan J, Mechanisms and epidemiology of trauma. In: Wilson WC, Grande CM, Hoyt DB, editors. Trauma emergency resuscitation perioperative anesthesia surgical management Vol. 1. New York: Informa Healthcare, 2007; p.25-42.

3. Dutton RP, Howard RS. Fluid resuscitation strategy. In: Wilson WC, Grande CM, Hoyt DB, editors. Trauma emergency resuscitation perioperative anesthesia surgical management Vol. 1. New York: Informa Healthcare, 2007; p.21534.

4. Joy MA, Marciniak D, Petelenz-Rubin K, Establishing vascular access in the trauma patient. In: Smith CE, editor. Trauma anesthesia. Cambridge: Cambrigde University Press, 2008; p.69-80.

5. Morgan GE Jr, Mikhail MS, Murray MJ. Clinical anesthesiology (Fourth Edition). New York: McGraw-Hill Companies Inc, 2006.

6. Novikov M, Smith CE. Fluid and blood therapy in trauma. In: Smith CE, editor. Trauma anesthesia. Cambridge: Cambrigde University Press, 2008; p.101-20.

7. Jackson K, Nolan J. The role of hypotensive resuscitation in the management of trauma. JICS. 2009 
12 Jurnal Biomedik, Volume 4, Nomor 1, Maret 2012, hlm. 5-12

Apr;2(10):109-14.

8. Hawkinberry DW, Minokadeh A. Initial circulation assessment and shock prevention. In: Wilson WC, Grande CM, Hoyt DB, editors. Trauma emergency resuscitation perioperative anesthesia surgical management Vol. 1.

New York: Informa Healthcare, 2007; p.235-46.

9. Dutton RP, Mackenzie CF, Scalea TM. Hypotensive resuscitation during active hemorrhage: Impact on in-hospital mortality. J Trauma. 2002 Jun;52:11411146. 